\title{
Plasma Darah dalam Makanan daripada Perspektif Islam dan Sains
}

(Blood Plasma in Food from Islam and Science Perspectives)

\author{
MOHD IZHAR ARIFF MOHD KASHIM*, NUR ASMADAYANA HASIM, RIZAFIZAH OTHAMAN, MOHAMMAD ZAINI YAHAYA, \\ ROZIDA KHALID, MUHAMMAD ADIB SAMSUDIN \& DiANI MARDIANA MAT ZIN
}

\begin{abstract}
ABSTRAK
Makanan dan minuman yang halal dan baik merupakan tuntutan dalam Islam. Pada zaman serba moden ini, timbul kebimbangan terhadap status halal plasma darah yang digunakan secara meluas terutamanya dalam industri makanan. Objektif penyelidikan ini ialah untuk mengkaji kegunaan, kebaikan dan keburukan plasma darah serta pandangan ulama mengenai isu ini. Kajian ini dijalankan dengan menggunakan ulasan kepustakaan secara deskriptif. Kajian mendapati bahawa plasma darah mempunyai kemampuan melarut dan pengemulsi yang tinggi, kelikatan yang rendah serta kemampuan untuk membentuk gel yang kuat. Selain itu, plasma darah boleh menambah baik tekstur dan menjadi pengikat dalam penghasilan produk makanan moden. Ia juga merupakan alternatif protein yang murah bagi pengganti lemak dalam penghasilan produk daging rendah lemak. Walau bagaimanapun, kajian mendapati plasma darah mengandungi pelbagai mikroorganisma dan hasilan metabolisme yang berkemungkinan merbahaya akibat daripada toksin dan protein darah. Kini, terdapat pelbagai kaedah pengesanan yang boleh dijalankan untuk mengesan plasma darah dalam makanan bagi menentukan status halal. Terdapat dua pandangan berkenaan hukum penggunaan plasma darah, pandangan pertama bersependapat, penggunaan plasma darah dalam produk makanan adalah harus jika telah berlaku proses istihalah yang sempurna. Manakala pandangan kedua, mengharamkan plasma darah kerana ia adalah proses tidak sempurna (istihalah fasidah). Oleh itu, penentuan hukum terhadap istihalah dalam penghasilan plasma darah mestilah menepati kehendak syariat Islam di samping memastikan hukum berkaitan isu ini tidak ketinggalan zaman.
\end{abstract}

Kata kunci: Halal; istihalah; kebaikan; keburukan; plasma darah

ABSTRACT

Food and drink that were good (Halalan Toyyiban) is a compulsory in Islam. In this modern era, a concern was raised over the halal status of blood plasma that is widely used especially in the food industry. The objective of this study was to investigate the usefulness, advantages and disadvantages of the blood plasma as well as the views of Islamic scholars on this issue. The study was conducted using descriptive literature review. The study found that blood plasma has the ability to dissolve and high emulsifying, low viscosity and the ability to form a strong gel. Besides, it can improve the texture and be a binder in the production of modern food. It is a cheap alternative protein as fat substitute to be use in the production of low-fat meat products. Despite of the fact, the study found blood plasma contains various microorganisms and potentially harmful products of toxins and blood protein. In fact, products containing blood plasma is likely to cause allergy-induced protein content of blood. Now, there are a variety of detection methods that can be used to detect blood plasma in order to determine the halal status of food. There are two views regarding the legal use of blood plasma, first, the use of blood plasma in food products are allowed if it had a perfect process of changes, istihalah. Meanwhile a second opinion, to ban the blood plasma products as it has undergone an imperfect process of change, (istihalah fasidah) which results in the end material categorized as Haram. Therefore, law determination (Hukum) of istihalah in the production of blood plasma must meet the requirements of Islamic law while ensuring that the relevant legal issue is not outdated.

Keywords: Advantages; blood plasma; disadvantage; Halal; istihalah

\section{PENGENALAN}

Agama Islam merupakan agama yang sangat menekankan kesihatan dan nyawa manusia. Allah SWT memerintahkan kepada para hamba-Nya untuk memilih makanan atau minuman yang baik (halalan tayyiban). Sebaliknya, makanan dan minuman yang mempunyai kesan buruk, sama ada pada zat atau faktor luaran, ia dilarang untuk dimakan (Nor Fadilah 2013). Perkara ini dapat dibuktikan menerusi sabda Nabi SAW yang bermaksud: “Janganlah kamu memudaratkan diri kamu dan orang lain" (Ibn Majah 1999: Hasan Sahih).

Makanan dan minuman adalah sumber tenaga dan keperluan fisiologi yang perlu dipenuhi untuk kelangsungan kehidupan seharian manusia. Selain itu, Islam juga turut menjadikan pengambilan makanan yang halal bagi tujuan pengabdian diri kepada Allah SWT sebagai langkah memperoleh ganjaran syurga di akhirat kelak (Mohd Izhar Ariff 2013). Perkara ini sejajar dengan 
firman Allah SWT dalam al-Quran surah al-Nahl ayat 114115:

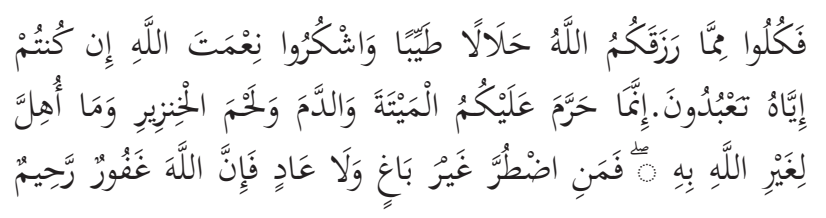

Maksudnya:

Oleh itu, makanlah (wahai orang-orang yang beriman) dari apa yang telah dikurniakan Allah kepada kamu dari benda-benda yang halal lagi baik dan bersyukurlah akan nikmat Allah, jika benar kamu hanya menyembahNya semata-mata. Sesungguhnya Allah hanya mengharamkan kepada kamu memakan bangkai, dan darah, dan daging babi, dan binatang yang disembelih tidak kerana Allah maka sesiapa terpaksa (memakannya kerana darurat) sedang ia tidak mengingininya dan tidak melampaui batas (pada kadar benda yang dimakan itu, maka tidaklah ia berdosa), sesungguhnya Allah Maha Pengampun, lagi Maha Mengasihani.

Pemilihan makanan bergantung kepada cara hidup, budaya, agama, diet dan kesihatan pengguna. Bagi Muslim, keputusan dalam memilih sesuatu makanan bergantung kepada status halal makanan tersebut yang telah ditegaskan dalam kitab suci al-Quran (Nakyinsige et al. 2012). Gaya hidup masa kini memerlukan segalanya dalam bentuk yang termudah yang menjadikan pengguna lebih memilih untuk mengambil makanan segera dan terproses yang kebanyakannya mengandungi plasma darah sebagai penambah makanan (Ali et al. 2012). Di samping itu, produk makanan segera yang dijual di pasaraya atau kedai runcit tersedia dalam beraneka jenama, kemasan, cita rasa, tekstur dan harga; mudah menambat hati pengguna (Desmelati et al. 2011).

Peredaran zaman dan teknologi moden dalam penghasilan makanan telah menyebabkan kebimbangan dalam kalangan ulama kontemporari seperti al-Buty (1998). Ini kerana telah wujud usaha mencampuradukkan bahan haram dengan bahan halal dalam makanan seperti darah mengalir yang telah diubah suai kepada serbuk dan kemudian diproses menjadi produk makanan moden yang meragukan. Lebih membimbangkan apabila terdapat industri makanan hari ini yang menggunakan darah babi, lembu dan terbitannya seperti plasma dan sel-sel merah sebagai sebahagian daripada ramuan makanan yang dijual dalam bentuk serbuk kering (Dailloux et al. 2002; Saguer et al.2007). Plasma darah yang dijual dalam bentuk serbuk dikeringkan menggunakan kaedah semburan kering bagi menghasilkan nilai biologi yang tinggi serta ciri berfungsi yang terdapat daripadanya (Saguer et al. 2007).

Umumnya, darah ialah bahan buangan yang perlu dilupuskan mengikut prosedur tertentu. Kini, plasma darah diekstrak daripada bahan buangan tersebut untuk dijadikan nilai tambah dalam produk makanan moden. Pada tahun 2001, industri makanan dianggarkan telah mengambil manfaat daripada darah di tempat penyembelihan haiwan sebanyak 30\% dan dianggar meningkat saban tahun (Ofori \& Hsieh 2012). Kebelakangan ini, terdapat beberapa isu yang dikaitkan dengan penambahan plasma darah haiwan sembelihan seperti lembu dan babi di dalam produk daging (Norfadzilah 2016). Isu ini menimbulkan keraguan terhadap status halal sesetengah produk berasaskan daging haiwan. Walaupun kuantiti penggunaan plasma darah haiwan rendah, tetapi kesannya terhadap struktur makanan dapat dilihat terutama melalui peningkatan ciri produk daging terproses (Norfadzilah 2016).

\section{PLASMA DARAH}

Darah manusia dan vertebrata lainnya merupakan cairan tubuh berwarna merah yang terdiri daripada plasma darah dan sel darah. Terdapat dua kaedah yang boleh digunakan untuk memisahkan darah kepada pecahannya. Pertama, kaedah pengemparan yang menghasilkan sel darah merah dan plasma. Kedua, kaedah pembekuan untuk mengasingkan sel darah merah dan serum (Bah et al. 2013). Rajah 1 menunjukkan peratusan komponen selular darah menggunakan kaedah pengemparan Herlihy (2014). Fournier (2011) melaporkan bahawa komponen selular darah terdiri daripada $45 \%$ sel darah merah, $55 \%$ plasma, $4.9 \%$ platlet dan $0.1 \%$ sel darah putih.

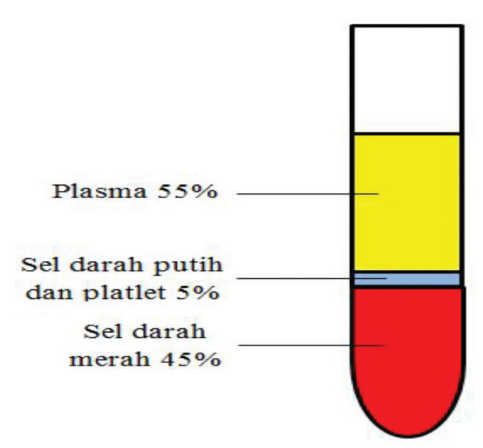

RAJAH 1. Peratusan komponen selular darah (Barbara 2014)

Plasma darah terdiri dari $91-92 \%$ air, $8.9 \%$ protein, $0.9 \%$ garam-garam tak organik serta bahan lain. Menurut Bishop et al. (2010) plasma darah terdiri daripada $92 \%$ air, $8 \%$ bahan larut seperti glukosa, protein, vitamin, mineral, urea, asid urik, karbon dioksida, hormon dan antibodi. Protein plasma pada darah vetebrata umumnya terdiri daripada albumin, globulin dan fibrinogen (Herrero et al. 2009; Rumanta 2007).

Kini, plasma darah yang telah dihidrat digunakan sebagai ramuan protein yang membawa kepada ciri gel di dalam sesetengah makanan, terutamanya berasaskan daging (Benjakul et al. 2001b; Dailloux et al. 2002). Rawatan terma yang dikenakan ke atas protein plasma menggalakkan denaturasi dan aggregasi yang menghasilkan hubungan tiga dimensi yang menyebabkan gel yang konsisten terhasil (Dàvila et al. 2007; Herrero et al. 2009). Oleh itu, industri pemprosesan makanan mengambil peluang ke atas keupayaan protein plasma menghasilkan gel bagi mengekalkan tekstur produk daging 
yang telah dimasak (Cofrades et al. 2000; Herrero et al. 2009; Pietrasik et al. 2007). Malah, industri daging juga menghasilkan modifikasi tekstur dengan menggunakan pengikat terutamanya fibrinogen dan trombin yang diperoleh daripada darah (Herrero et al. 2009). Terkini, enzim pembekuan darah trombin telah digunakan bersama dengan plasma darah sebagai pengikat daging dalam pemprosesan daging potong atau daging cincang (Grundy et al. 2008).

\section{KEGUNAAN PLASMA DARAH SEBAGAI ADITIF MAKANAN}

Aditif makanan ialah bahan yang dimasukkan ke dalam makanan bagi meningkatkan kualiti, keenakan dan keunikan makanan. Plasma darah masa kini diproses dan dimanfaatkan dalam bentuk aditif makanan (Sa'dom et al. 2008). Penggunaan plasma darah dalam produk makanan menjadi pilihan sebahagian pengeluar produk berasaskan daging seperti daging kisar, bebola ikan dan bebola daging (Benjakul et al. 2001b). Ini kerana plasma darah mempunyai kemampuan melarut dan mengemulsi yang tinggi, kelikatan yang rendah serta kemampuan untuk membentuk gel yang kuat. Selain itu, ia boleh menambah tekstur dalam produk makanan diproses seperti daging dan ikan (Benjakul et al. 2001a; McDermott et al. 2004). Pengikat digunakan secara tradisi dalam produk daging untuk mengelakkan perubahan tekstur dan sensori kesan pemprosesan (Devadason et al. 2010). Plasma darah dan protein darah digunakan sebagai pengikat dalam industri daging. Fungsi plasma sebagai pengikat dalam sistem bergantung kepada keupayaannya untuk menghasilkan gel semasa pemanasan (Ofori \& Hsieh 2012). Daripada sudut ciri pengikatan, plasma darah ialah alternatif kepada telur yang digunakan secara tradisional dalam industri makanan (Hickson et al. 1980). Malah plasma darah juga didapati lebih efektif dan murah untuk menggantikan putih telur dalam pembuatan kek dan roti (Ofori \& Hsieh 2012).

Plasma darah sebagai pengemulsi dimanfaatkan dalam pengemulsian produk daging seperti sosej untuk mengikat protein daging, lemak dan air di dalam emulsi yang stabil. Plasma darah juga membantu penyebaran lemak dalam produk bagi memperoleh tekstur yang betul dan menghasilkan sensori produk akhir yang berkualiti (Wilde et al. 2004). Protein darah didapati mempunyai ciri pengemulsi yang setanding dan boleh menggantikan kasein (Ofori \& Hsieh 2012). Malah plasma darah dilaporkan mempunyai kapasiti pengemulsi lebih baik daripada globin darah terutamanya dalam pemprosesan sosej (Caldironi \& Ockerman 1982).

Lemak memainkan peranan penting dalam diet sebagai sumber vitamin, asid lemak dan tenaga (Mela 1990). Selain peranan nutrisi, lemak juga mempunyai kesan utama dalam kelembutan, ciri mengikat, juiciness dan menarik serta rasa lebih lazat (Drewnowski 1992). Kajian juga mendapati protein darah berpotensi sebagai pengganti lemak dalam produk daging. Malah, protein darah juga mengurangkan kandungan kalori makanan untuk setiap gram lemak yang diganti (Ofori \& Hsieh 2012). Terdapat kajian (Cofrades et al. 2000) dalam membandingkan kesan plasma dan serat soya sebagai pengganti lemak dalam sosej bologna mendapati protein plasma memberi lebih pengaruh kepada ciri pengikat dan tekstur, iaitu lebih baik berbanding protein soya. Plasma darah menyediakan satu alternatif protein yang murah bagi kegunaan pengganti lemak dalam penghasilan produk daging rendah lemak (Ofori \& Hsieh 2012).

\section{KEBAIKAN PLASMA}

Jadual 1 menunjukkan jumlah peratusan kandungan amino asid dalam protein plasma. Data ini menunjukkan nilai biologi plasma yang tinggi dan membuktikan kelebihannya terhadap bahan mentah yang selalu digunakan dalam pengeluaran sebagai aditif makanan (Kriger 2014).

Sebatian nitrogen yang hadir dalam plasma adalah tidak terhad kepada protein yang dikenali sahaja (albumin, globulin dan fibrinogen), plasma juga mengandungi asid amino, ammonia, hasilan metabolisme nukleotid purin dan pyrimidin. Kuantiti kandungan protein dalam plasma ialah $(9.5 \%)$ dan kandungan lembapan $(90.5 \%)$ adalah penting bagi menentukan keupayaannya dan menambah nilai fungsi sebagai aditif makanan (Kriger 2014).

JADUAL 1. Jumlah peratusan kandungan amino asid dalam protein plasma

\begin{tabular}{lccc}
\hline \multirow{2}{*}{$\begin{array}{l}\text { Keperluan asid } \\
\text { amino }\end{array}$} & \multicolumn{3}{c}{ Kandungan jumlah $(\%)$ asid amino } \\
\cline { 2 - 4 } & Fibrinogen & Globulin & Albumin \\
\hline Phenylalanin & 7.0 & 3.8 & 6.2 \\
Tryptofan & 3.5 & 2.3 & 0.6 \\
Arginin & 6.7 & 5.2 & 6.2 \\
Histidin & 2.3 & 3.5 & 3.8 \\
Lysin & 9.0 & 6.2 & 12.4 \\
Methionin & 2.6 & 1.0 & 1.3 \\
Threonin & 7.9 & 8.4 & 6.5 \\
Leucin & 14.3 & 18.5 & 13.7 \\
Isoleucin & 5.0 & & 2.9 \\
Valin & 3.9 & 5.5 & 0.5 \\
\hline
\end{tabular}

Sumber: Kriger 2014 
Selain itu, enzim trombin dan fibrinogen diperoleh daripada darah plasma. Trombin: Fibrinogen digunakan ke atas daging dengan trombin mengubah fibrinogen kepada fibrin yang berinteraksi dengan kolagen yang berupaya mengikat cebisan daging. Enzim ini juga digunakan dalam ternakan, ikan dan makan laut. Trombin dan fibrinogen diperoleh daripada bahagian haiwan yang boleh dimakan, yang tidak memerlukan ujian toksikologi. Jadual 2 menunjukkan contoh produk protein darah komersial daripada plasma darah yang digunakan sebagai penambah makanan (Ofori \& Hsieh 2012). Penggunaan produk daging yang mengandungi penyediaan enzim ini dilihat tidak meningkatkan risiko alahan atau tindak balas ketidaktoleransi (Anton 2005).

\section{KELEMAHAN/KEBURUKAN PLASMA DARAH}

Islam melarang pengambilan darah haiwan kerana ia dipercayai mengandungi pelbagai mikroorganisma dan hasilan metabolisma yang berkemungkinan merbahaya dan toksin (al-Qabisy 2012; Eliasi \& Dweyer 2002). Kajian mendapati produk yang mengandungi plasma darah berkemungkinan menyebabkan alahan yang disebabkan kandungan protein darah seperti serum albumin dan $\operatorname{IgG}$. Serum albumin bovin mewakili protein yang paling banyak (50\%-60\%) dalam pecahan plasma darah lembu (Davíla et al. 2007). Terdahulu, media Bismuth Sulfite Agar (BSA) yang digunakan untuk menguji daging dan susu lembu didapati telah dikaitkan tindak balas alahan ke atas susu (Takahata et al. 2000) dan produk berasaskan daging (Maeda et al 1993).

Kandungan mikrobiologi terutamanya Salmonella di dalam produk protein haiwan adalah tinggi berbanding dengan produk protein tumbuhan (DeRouchey et al. 2003) dan memberi perbezaan dalam tindak balas pertumbuhan yang dapat dilihat pada haiwan. Dalam perkilangan makanan haiwan berasaskan darah, darah berbentuk cecair boleh disimpan pada suhu $5^{\circ} \mathrm{C}$ untuk beberapa hari selepas pengumpulannya sebelum ia kering. Semasa tempoh penyimpanan ini, populasi mikrob dalam darah berbentuk cecair akan meningkat dan $\mathrm{pH}$ akan menurun (DeRouchey et al. 2003). Radiasi dibuktikan merupakan satu kaedah yang efektif untuk mengurangkan tahap bakteria dalam produk darah yang dikeringkan (DeRouchey et al. 2003; Turubatovic et al. 1993).

Kajian oleh Uchman et al. (1986) mendapati pada awal pengumpulan, plasma cecair mempunyai kepekatan bakteria pada kadar daripada $1.5 \times 10^{6}$ hingga $3.2 \times 10^{6}$ $\mathrm{cfu} / \mathrm{g}$. Selepas radiasi, kiraan bakteria berkurang secara linear daripada $3.5 \times 10^{1}$ hingga $0 \mathrm{cfu} / \mathrm{g}$ mengikut dos radiasi yang meningkat. Bagi kepekatan awal plasma yang disembur kering sebelum radiasi ialah $2.2 \times 10^{3}$ hingga $4.3 \times 10^{3} \mathrm{cfu} / \mathrm{g}$ dan berkurang selepas radiasi daripada $2.0 \times 10^{3} \mathrm{ke} 0 \mathrm{cfu} / \mathrm{g}$ dengan peningkatan dos radiasi. Namun selepas penyimpanan selama 48 jam plasma cecair yang dikenakan radiasi pada $4.0 \mathrm{kGy}$ menunjukkan tahap bakteria meningkat ke tahap sebelum radiasi. Berbeza dengan plasma semburan kering yang tahap bakterianya hanya meningkat sedikit dan tahap pencemaran adalah stabil dan rendah berbanding yang tidak diradiasi. Malah tiada kehadiran yis dan kulat pada plasma kering. Hal ini disokong dalam kajian oleh DeRouchey et al. (2003) produk makanan haiwan berasaskan darah telah membuktikan kandungan bakteria pada produk tanpa radiasi gama adalah seperti Jadual 3.

JADUAL 2. Protein daripada plasma darah yang digunakan sebagai aditif makanan

\begin{tabular}{llll}
\hline Produk & Syarikat & Sumber darah & Huraian \\
\hline Fibrimex & Sonac BV, Netherlands & Porsin atau bovin & Protein trombin dan fibrinogen protein yang diisolasi \\
Serbuk Plasma FG & Sonac BV, Netherlands & Porsin atau bovin & Plasma dengan kepekatan fibrinogen yang tinggi \\
PP & Sonac BV, Netherlands & Porsin atau bovin & Plasma sejuk beku atau serbuk \\
Prolican 70 & Lican Functional Protein Source, & Porsin & Semburan-kering kepekatan plasma bovin \\
& Chile & & \\
Plasma & Veos NV, Belgium & Porsin atau bovin & Cecair, serbuk, sejuk-beku atau kepingan plasma \\
\hline
\end{tabular}

Sumber: Ofori \& Hsieh 2012 dengan sedikit pengubahsuaian

JADUAL 3. Kandungan bakteria pada makanan haiwan berasaskan darah tanpa radiasi $(\mathrm{cfu} / \mathrm{g})$

\begin{tabular}{lc}
\hline Jenis bakteria & $\begin{array}{c}\text { Kandungan bakteria pada makanan } \\
\text { berasaskan darah tanpa radiasi }(\mathrm{cfu} / \mathrm{g})\end{array}$ \\
\hline Bakteria Aerobik & $7.9 \times 10^{6}$ \\
E.Coli & $2.3 \times 10^{3}$ \\
Yis dan kulat & $2.4 \times 10^{2}$ \\
\hline
\end{tabular}

Sumber: DeRouchey 2003 


\section{PENGESANAN PLASMA DARAH}

Industri makanan menggunakan plasma darah sebagai agen pengikat dalam produk daging. Sebagai contoh dalam penghasilan produk surimi, pada dasarnya, surimi dihasilkan daripada rencah isi ikan. Namun disebabkan tahap kekentalannya yang rendah, pihak industri telah mencampurkannya dengan bahan pengental berasaskan serbuk protein plasma darah bagi mengatasi masalah tersebut (Muhammad Aizat \& Che Wan Jasimah 2009). Walau bagaimanapun, penggunaan darah dalam makanan adalah dilarang mengikut Islam (al-Nawawi t.th; Nakyinsige et al. 2012). Bukti saintifik adalah penting dalam pengesahan halal. Di Malaysia, permohonan pensijilan halal bagi mematuhi piawai dan integriti halal produk makanan dipantau dengan tegas oleh pihak berkuasa Jabatan Kemajuan Islam Malaysia (JAKIM) (Sahilah et al. 2012). Oleh itu, teknik untuk mengesan plasma darah dalam makanan untuk pengesahan halal diperlukan (Nakyinsige et al. 2012). Bauer dan Stachelberger (1984) berjaya mengesan plasma darah dalam produk daging rawatan haba menggunakan lapisan ultra nipis terfokus isoelektrik. Bagi mengatasi cabaran pengenalpastian plasma darah dalam produk daging, Kementerian Pertanian, Perikanan dan Makanan UK (MAFF) ditugaskan penyelidikan menggunakan imunoresapan dan ELISA(Hargin 1996). Penyebaran imun ganda dua dalam agar-gel hanya mampu mengesan $8 \%$ antibodi dalam daging lembu dimasak dan $1 \%$ dalam daging babi mentah. Protokol ELISA adalah lebih berkesan iaitu dapat mengesan $0.2 \% \mathrm{~m} / \mathrm{m}$ sebagai plasma kering. Walaupun kedua-dua teknik tidak dapat membezakan asal-usul spesies, ia cukup untuk pengesahan halal kerana mengikut keperluan adalah untuk mengesahkan kehadiran atau ketiadaan plasma darah yang ditambah dalam produk.

Kromatografi cecair tri-caturkutub spektrometri jisim telah berjaya digunakan untuk menyaring penambahan agen pengikat berasaskan darah bovin (Grundy et al. 2007) dan porsin (Grundy et al. 2008) dalam produk daging. Terkini, Norfadzilah (2016) membuktikan bahawa tindak balas berantai polimerase (PCR) secara simpleks dapat membantu dalam pengujian kehadiran DNA haiwan dalam produk Halal walaupun telah melalui pelbagai proses. Manakala tindak balas berantai polimerase (PCR) secara multipleks pula mampu mengenal pasti pelbagai DNA haiwan pada sampel produk dalam masa yang singkat dan lebih efisyen. Jadual 4 menunjukkan satu ringkasan gambaran teknik analisis bagi mengesan kehadiran plasma darah dalam daging dan produk daging.

\section{HUKUM DAN APLIKASI ISTIHALAH TERHADAP MAKANAN BERASASKAN PLASMA DARAH HAIWAN}

Al-Quran mengharamkan segala jenis makanan dan minuman daripada sumber darah yang mengalir. Ia dapat dibuktikan menerusi firman Allah dalam surah al-An'am ayat 145 :

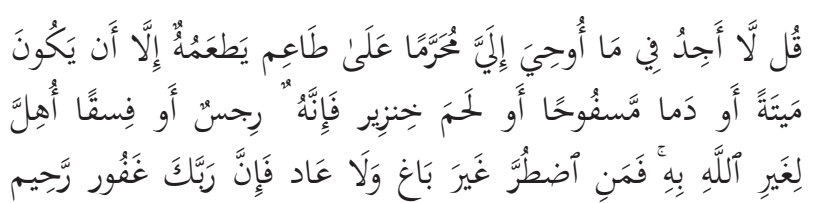

Maksudnya:

Katakanlah (wahai Muhammad): Aku tidak dapati dalam apa yang telah diwahyukan kepadaku, sesuatu yang diharamkan bagi orang yang hendak memakannya melainkan kalau benda itu bangkai atau darah yang mengalir atau daging babi kerana sesungguhnya ia adalah kotor atau sesuatu yang dilakukan secara fasik, iaitu haiwan yang disembelih atas nama yang lain dari Allah. Kemudian sesiapa yang terpaksa (memakannya kerana darurat) sedang dia tidak mengingininya dan tidak melampaui batas, maka sesungguhnya Tuhan mu Maha Pengampun, lagi Maha Mengasihani.

Walau bagaimanapun, penentuan hukum ini tidaklah berlaku ke atas semua produk tetapi ia dilihat daripada aspek keperluan umum. Oleh sebab itu, para ulama terpaksa meneliti terlebih dahulu kes demi kes agar hukum yang ditetapkan itu tidak menyusahkan kehidupan umat Islam. Malah, sebahagian ulama kontemporari menggunakan konsep istihalah dalam menentukan hukum plasma darah dalam makanan moden (Mohd Izhar Ariff et al. 2015).

Menerusi perkembangan teknologi moden pada hari ini, setiap produk makanan yang mengandungi plasma darah boleh dikesan dan dianalisis kandungannya dengan mudah. Dalam Islam, prinsip istihalah boleh diguna pakai untuk menyelesaikan permasalahan yang berkaitan penggunaan plasma darah dalam makanan (Mohd Izhar Ariff et al. 2015).

Konsep istihalah boleh dijelaskan menerusi kaedah mengubah sesuatu bahan sama ada dengan proses semula jadi atau menerusi proses teknologi moden kepada bahan lain hingga berlaku pertukaran zat dan sifat. Pertukaran zat

JADUAL 4. Ringkasan teknik analisis bagi mengesan plasma darah dalam daging dan produk daging

\begin{tabular}{cll}
\hline Isu & \multicolumn{1}{c}{ Teknik Analisis } & \multicolumn{1}{c}{ Rujukan } \\
\hline Kehadiran plasma darah & Isoelectric focusing & Bauer dan Stachelberger (1984) \\
& ELISA & Church dan Hart (1995) \\
& Immunodiffusion & Price, Hart, dan Church (1992) \\
& LC-MS/MS & Grundy et al. (2007) dan Grundy et al. (2008) \\
Pengecaman sumber plasma darah & PCR simplex \& multiplex & Norfadzilah (2016) \\
\hline
\end{tabular}

Sumber: Nakyinsige et al. (2012) dengan sedikit pengubahsuaian 
dan sifat itu pula adakalanya berlaku secara sempurna dan adakalanya tidak sempurna. Perubahan secara sempurna berlaku apabila plasma darah tidak dapat dikesan dalam produk makanan yang terhasil. Manakala perubahan tidak sempurna pula berlaku apabila plasma darah masih dapat dikesan menerusi kaeadah PCR dan seumpamanya (Mohd Izhar Ariff 2013).

\section{PANDANGAN ULAMA MENEGANI PROSES ISTIHALAH} PLASMA DARAH DALAM MAKANAN

Dalam isu istihalah, ulama Islam terbahagi kepada dua pandangan. Pandangan pertama telah menghalalkan penggunaan istihalah dalam makanan jika sifat asalnya telah berubah kepada produk yang baharu. Pandangan ini dipelopori oleh mazhab Hanafi (Ibn Nujaym t.th.) mazhab Maliki (Ibn al-Juzayr 1991), Ibn al-'Arabi (t.th), Ibn alQayyim (1992) dan Ibn Hazm (1988), Ibn Taymiyyah (1988). Hujah pandangan ini ialah umum firman Allah SWT dalam surah al-An'am ayat 145 yang mengharamkan darah mengalir untuk dimakan atau diminum. Illah pengharaman adalah 'darah mengalir' dan ia tidak lagi berlaku ke atas plasma darah. Perlu diingatkan bahawa penghasilan plasma darah dalam produk makanan telah berlaku menerusi proses istihalah yang sempurna apabila identiti darah tidak dapat dilihat dengan mata zahir. Maka penggunaan plasma darah adalah dibenarkan dalam Islam (Mohd Izhar Ariff et al. 2015).

Manakala pandangan kedua pula dipelopori oleh mazhab Syafie (al-Nawawi t.th) dan Hanbali (Ibn alQudamah 1979). Mereka berpendapat bahawa proses istihalah tidak boleh diguna pakai kecuali terhadap tiga keadaan sahaja. Keadaan pertama, arak yang bertukar menjadi cuka dengan sendirinya tanpa campur tangan manusia. Kedua, kulit dan bulu haiwan yang mati selain daripada anjing dan babi setelah ia disamak. Ketiga, sesuatu yang berubah menjadi haiwan seperti bangkai berubah menjadi ulat kerana berlaku suatu kehidupan yang baharu. Hujah pandangan kedua ini lebih kepada kaedah 'sad al-dhara'i' iaitu menutup pintu-pintu keburukan dalam penghasilan produk makanan. Selain itu, hujah mereka juga ialah mengambil langkah berhati-hati sepaya tidak terjebak dalam haram 'al-ihtiyat' (Muhammad Safiri 2010).

Pandangan ini turut disokong oleh sebahagian penyelidik Malaysia daripada Universiti Malaya seperti Muhammad Aizat dan Che Wan Jasimah (2009). Ini kerana proses istihalah plasma darah dalam produk makanan moden tidak berlaku dengan sempurna dan ia dikira sebagai istihalah fasidah atau rosak. Jika sesuatu produk mengalami proses istihalah fasidah, bahan akhir yang terhasil dikategorikan sebagai haram. Namun begitu, dalam kes-kes tertentu, ia boleh berkemungkinan berubah menjadi halal kembali (Muhammad Aizat \& Che Wan Jasimah 2009).

Setelah diteliti dua pandangan tersebut, didapati pandangan pertama lebih sesuai untuk diguna pakai terhadap penentuan hukum plasma darah dalam makanan moden. Ini kerana kemajuan teknologi moden khususnya dalam penghasilan produk makanan moden begitu maju sekali hingga proses istihalah sempurna telah berlaku dan produk berasaskan plasma darah dapat dianalisis kebaikan dan keburukannya kepada kehidupan manusia (Mohd Izhar 2013). Walaupun begitu, penentuan hukum terhadap istihalah dalam penghasilan plasma darah tidak boleh diambil mudah. Kajian terperinci perlu supaya ia benar-benar menepati kehendak syariat Islam. Oleh itu, para ulama kontemporari perlu mematuhi struktur dan teori istihalah agar penentuan hukum berkaitan isu ini tidak ketinggalan zaman (Muhammad Aizat \& Che Wan Jasimah 2009).

Antara isu yang akan dianalisis menggunakan instrumen istihalah ialah produk makanan berasaskan plasma daripada darah haiwan. Darah merupakan cecair merah yang mengalir dalam urat darah (Qal'aji 1996). Ia dikategorikan sebagai najis dan mendatangkan kemudharatan (alMaraghi 1946). Ini kerana pengharamannya telah jelas di dalam al-Qur'an dan al-Sunnah. Allah SWT menjelaskan mengenai pengharaman darah yang mengalir, daging babi dan haiwan yang disembelih bukan atas nama Allah. Semua perkara ini terdapat di dalam surah al-An'am ayat 145 sebelum ini.

Berdasarkan kepada ayat di atas, secara umumnya ijma telah berlaku dalam kalangan ulama dalam mengharamkan darah yang mengalir sahaja kerana ia adalah najis (al-Haqq t.th). Pengharaman ini tidak termasuk darah haiwan air seperti ikan, jantung, limpa dan hati serta sumber darah yang berada dalam saraf haiwan selepas ia disembelih selagi ia tidak mengalir (al-Zuhayli 1997) dan termasuklah darah yang masih kekal selepas dibasuh. Kebanyakan para ulama kontemporari seperti al-Qaradāwī (1993) dan alZuhayli (1997) serta Sa'id Hawwa (1994) bersependapat dalam mengharuskan penggunaan plasma darah dalam produk makanan jika telah berlaku proses istihalah yang sempurna. Isu ini terkecuali daripada larangan yang terdapat dalam surah al-An'am ayat 145 yang lebih bersifat khusus kepada darah mengalir sedangkan sifat itu tidak ada dalam serbuk plasma darah. Namun begitu, kadar penggunaan mestilah dengan kadar yang sedikit iaitu sekadar mengurangkan risiko kerosakan terhadap daging kisar (Mohd Izhar Ariff et al. 2015). Pandangan yang mengharuskan menggunakan plasma darah turut disokong oleh sarjana Islam lain seperti Abd al-Majid (1991) dan Waleed Khalid (2007). Beliau berpendapat adalah harus menggunakan sebahagian daripada elemen darah contohnya enzim, plasma (platelet), sel darah putih atau merah. Ini kerana ia bukan keseluruhan darah yang dimaksudkan oleh nas al-Qur'an dan al-Sunnah.

\section{KESIMPULAN}

Plasma darah mempunyai pelbagai kegunaan dan kebaikan yang menjadi nilai tambah dalam produk makanan pada masa kini. Selain bersifat mudah larut, mengemulsi yang tinggi, kelikatan yang rendah dan mampu membentuk gel yang kuat, plasma darah juga 
boleh digunakan untuk menambah baik tekstur dan menjadi satu alternatif pengganti lemak yang murah dan rendah lemak. Namun, plasma darah juga mempunyai kelemahan kerana mempunyai mikroorganisma yang berbahaya dan boleh menyebabkan alahan daripada protein darah. Islam mempunyai dua pandangan berbeza mengenai hukum penggunaan plasma darah dalam makanan iaitu, ulama kontemporari mengharuskan manakala mengikut mazhab syafie' dan mazhab hambali, plasma darah adalah diharamkan. Penentuan hukum ini juga bergantung kepada proses istihalah yang digunakan dalam penghasilan plasma darah. Oleh itu, penentuan hukum terhadap istihalah dalam penghasilan plasma darah mestilah menepati kehendak syariat Islam di samping memastikan hukum berkaitan isu ini tidak ketinggalan zaman.

\section{PENGHARGAAN}

Pengarang mengucapkan terima kasih kepada Universiti Kebangsan Malaysia untuk kod projek penyelidikan FRGS/2/2013/SSI03/UKM/03/2, GGP-2014-016 dan DPP2015-FPI yang telah memberi sokongan sehingga terhasilnya penulisan ini.

\section{RUJUKAN}

al-Buty, Muhammad Said Ramadhan. 1998. Ma'al-Nas. Beyrut, Lubnan: Dar al-Kutb al-Ilmiyyah. hlm. 73.

Abd al-Majid Mahmood Salihin. 1991. Ahkam al-Najasat fi Fiqh al-Islami. Jeddah: Dar al-Majma'. hlm. 115.

Ali, M.E., Hashim, U., Dhahi, T.S., Mustafa, S., Man, Y. \& Latif, M.A. 2012. Analysis of pork adulteration of commercial burgers targeting porcine-specificmitochondrial cytochrome B gene by TaqMan probe real-time polymerase chain reaction. Food Analytical Methods 5(4): 784-794.

Abu Muhammad 'Abd al-Haqq bin Ghalib bin 'Atiyyah alAndalusi. t.th. alMuharrar al-Wajiz fi Tafsir al-Kitab al-'Aziz, juz. 1, Beirut: Dar al-Kutub al- 'Ilmiyyah, hlm. 240.

al-Maraghi, Ahmad Mustafa 1946. Tafsir al-Maraghi, juz. 1, Mesir: Syarikah Maktabah wa Matba'ah Mustafa al-Halabi. hlm. 49.

al-Nawawi, Mahy al-Din ibn Sharaf. t.th. Al-Majmuc ${ }^{c}$ Jil. 9. Bayrut: Dar Ihya' al-Turath al-'Arabi. hlm. 213.

al-Quran. Surah al-Nahl 16: 114-115 dan al-An'am 6: 145.

al-Qabisy, Muhammad Adib. 2012. Fiqh al-at'imah wa alashribah. Jorden: Dar al-Ma'rifah. hlm. 58.

al-Qaradāwī, Yusuf. 1993. Fatawa Mucasarah. Jil. 2. al-Qāhirah: Dār al-Wafā'. Mansūrah. hlm. 124.

al-Zuhayli, Wahbah 1997. al-Fiqh al-Islami wa Adillatuh, juz. 1, cet. 4, Damsyik: Dar al-Fikr. hlm. 100.

Anton, R. 2005. Opinion of the scientific panel on food additives, flavourings, processing aids and materials in contact with food (AFC) related to use of an enzyme preparation based on trombin: Fibrinogen derived from cattle and/or pigs as a food additive for reconstituting food. The EFSA Journal 3: 1-8.

Bah, C.S.F., Bekhit, A.E.A., Carne, A. \& McConnell, M.A. 2013. Slaughterhouse blood: An emerging source of bioactive compounds. Comprehensive Reviews in Food Science and Food Safety 12(3): 314-331.

Bauer, F. \& Stachelberger, H. 1984. Detection of blood plasma in heat-treated meat products by ultra-thin layer isoelectric focusing. Z Lebensm Unters Forsch. 178(2): 86-89.
Benjakul, S., Visessanguan, W. \& Srivilai, J. 2001a. Porcine plasma protein as gel enhancer in bigeye snapper (Priacanthus tayenus) surimi. Journal of Food Biochemistry 25: 285-308.

Benjakul, S., Visessanguan, W. \& Srivilai, C. 2001b. Gel properties of bigeye snapper (Priacanthus tayenus) surimi as affected by setting and porcine plasma proteins. Journal of Food Quality 24: 453-471.

Bishop, M.L., Fody, E.P. \& Schoeff, L.E. 2010. Clinical Chemistry: Techniques, Principles, Correlations. 6th ed. Philadelphia: Lippincott Williams \& Wilkins. p. 268.

Caldironi, H.A. \& Ockerman, H.W. 1982. Incorporation of blood proteins into sausage. Journal of Food Science 4792): 405-408

Cofrades, S., Guerra, M.A., Carballo, J., Fernández-Martin, F. \& Jiménez Colmenero, F. 2000. Plasma protein and soy fiber content effect on bologna sausage properties as influenced by fat level. Journal of Food Science 65(2): 281-287.

Dailloux, S., Djelveh, G., Peyron, A. \& Oulion, C. 2002. Rheological behavior of blood plasmas concentrated by ultrafiltration and by evaporation in relation to liquid-gel transition temperature. Journal of Food Engineering 55(1): 35-39.

Dàvila, E., Parés, D., Cuvelier, G. \& Relkin, P. 2007. Heatinduced gelation of porcine blood plasma proteins as affected by $\mathrm{pH}$. Meat Science 76(2): 216-225.

DeRouchey, J.M., Hancock, J.D., Hines, R.H., Cummings, K.R., Lee, D.J., Maloney,C.A., Dean, D.W., Park, J.S. \& Cao, H. 2003. Effects of dietary electrolyte balance on the chemistry of blood and urine in lactating sows and sow litter performance. J. Anim. Sci. 81: 3067-3074.

Desmelati, Mohd Khan Ayob, Aminah Abdullah \& Abdul Salam Babji. 2011.Penilaian kualiti fiziokimia nuget ikan komersial. Sains Malaysiana 40(8): 871-875.

Devadason, I.P., Anjaneluyu, A.S.R. \& Babji, Y. 2010. Effect of different binders on the physic-chemical, textural, histological, and sensory qualities of retort pouched buffalo meat nuggets. Journal of Food Science 75(1): S31-S35

Drewnowski, A. 1992. Sensory properties of fats and fat replacements. Nutrition Reviews 50(4): 17-20.

Eliasi, J.R. \& Dwyer, J.T. 2002. Kosher and Halal: Religious observances affecting dietary intakes. Journal of the American Dietetic Association 102(7): 911-913.

Fournier, R.L. 2011. Basic Transport Phenomena in Biomedical Engineering. 3rd ed. New York: CRC Press. hlm. 121.

Grundy, H.H., Reece, P., Sykes, M.D., Clough, J.A., Audsley, N. \& Stones, R. 2008. Method to screen for the addition of porcine blood-based binding products to foods using liquid chromatography/triple quadrupole mass spectrometry. Rapid Communications in Mass Spectrometry 22(12): 2006-2008.

Grundy, H.H., Reece, P., Sykes, M.D., Clough, J.A., Audsley, N. \& Stones, R. 2007. Screening method for the addition of bovine blood-based binding agents to food using liquid chromatography triple quadrupole mass spectrometry. Rapid Communications in Mass Spectrometry 21(18): 2919-2925.

Hargin, K.D. 1996. Authenticity issues in meat and meat products. Meat Science 43(1): 277-289.

Herrero, A.M., Cambero, M.I., Ordonez, J.A., Hoz, L.D. \& Carmona, P. 2009. Plasma powder as cold-set binding agent for meat system: rheological and Raman spectroscopy study. Food Chemistry 113(2): 493-499.

Hickson, D.W., Dill, C.W., Morgan, R.G., Suter, D.A. \& Carpenter, Z.L. 1980. A comparison of heat-induced gel strengths of bovine plasma and egg albumen proteins. Journal of Animal Science 51: 69-73. 
Herlihy, B. 2014. The Human Body in Health and Illness. 5th ed. Philadelphia: Elsevier Health Sciences. hlm. 99.

Ibn al-Juzayr, Muhammad Ahmad. 1991. Al-Qawanin alFiqhiyyah. Bayrut: Dar al-Arqam. hlm. 162.

Ibn 'Arabi. t.th. Ahkam al-Qur'an. Jil. 2. Bayrut: Dar al-Kutub al-'Ilmiyyah. hlm. 171.

Ibn hazm, Ali ibn Ahmad. 1988. al-Muhalla. Cet. 4. Jil.3. Bayrut: Dar al-Kutub al-'Ilmiyyah, hlm. 120.

Ibn Majah, Muhammad ibn Yazid. 1999. Sunan Ibn Majah. Damascus, Syiria: Dar al-Bashair. No. Hadis: 1127.

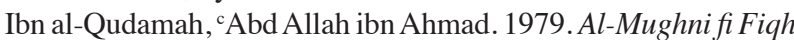
Imam al-Sunnah Ahmad ibn Hanbal. Cet. 1. Jil. 9. Bayrut: Dar Kutub al-'Ilmiyyah. hlm. 116.

Ibn Qayyim al-Jawziyyah, Muhammad ibn Abi Bakr. 1992. Rawdat al-Muhibbin. Bayrut: Dar al-Kutub al-cIlmiyyah. hlm. 201.

Ibn Taymiyyah, Ahmad ibn ${ }^{\mathrm{c} A b d}$ al-Halim. 1988. Al-Fatawa al-Kubra. Bayrut: Dar al-Macrifah.

Kriger, O.V. 2014. Advantages of porcine blood plasma as a component of functional drinks. Food and Raw Materials 2(2): 26-31

Maeda, S., Morikawa, A., Tokuyama, K. \& Kuroume, T. 1993. The concentration of bovine IgG in human breast milk measured using different methods. Acta Paediatrica 82(s385): 1012 - 1016.

McDermott, M.K., Tianhong, C., Williams, C.M., Markley, K.M. \& Payne, G.F. 2004. Mechanical properties of biomimetic tissue adhesive based on the microbial transglutaminasecatalyzed crosslinking of gelatin. Biomacromolecules 5(4): 1270-1279.

Mela, D.J. 1990. The basis of dietry fat preference. Trends in Food Science and Technology 1: 71-73.

Mohd Izhar Ariff Mohd Kashim 2013. Prinsip penentuan hukum makanan ubah suai genetik yang berasaskan haiwan. Tesis Ph.D. Jabatan Syariah, Fakulti Pengajian Islam, Universiti Kebangsaan Malaysia. hlm. 159 (tidak diterbitkan).

Mohd Izhar Ariff Mohd Kashim, Latifah Abdul Majid, Airil Haimi Mohd Adnan, Ahmad Bin Muhammad Husni, Zaini Nasohah, Mohd Adib Samsudin \& Muhammad Zaini Yahaya. 2015. Principles regarding the use of Haram (forbidden) sources in food processing: A critical Islamic analysis. Asian Social Science 11(22): 17-25.

Muhammad Aizat Jamaludin \& Che Wan Jasimah Wan Mohamed Radzi. 2009. Teori istihalāh menurut perspektif Islam dan sains: Aplikasi terhadap beberapa penghasilan produk makanan. Jurnal Syariah 17(1): 169-194.

Muhammad Safiri Ismail. 2010. al-Istihalah sebagai kaedah penentuan hukum makanan: Analisis terhadap isu makanan diubahsuai genetik. Dlm. Permasalahan Etika dalam Bioteknologi, disunting oleh Latifah Amin \& Abdul Latif Samian. Bangi: Institut Tamadun dan Alam Melayu. hlm. 103-110.

Nakyinsige, K., Che Man, Y. \& Sazili, A.Q. 2012. Halal authenticity issues in meat and meat products. Meat Science 91(3): 207-214.

Norfadzilah Ismail. 2016. Kesan kaedah pemanasan berbeza ke atas pengesanan DNA ayam di dalam bebola daging dengan menggunakan tindakbalas berantai polimerase (PCR). Tesis Ijazah Sarjana Sains. Jabatan Sains Makanan. Universiti Kebangsaan Malaysia (tidak diterbitkan).

Nor Fadilah. 2013. Jangan Makan Barang Haram! Dampak Buruk Asupan yang Dilarang Islam terhadap Kesehatan. Jogjakarta: Najah
Ofori, J.A. \& Hsieh, Y.H.P. 2012. The use of blood and derived products as food additives. In Food Additive, edited by ElSamragy, Y. InTech. hlm. 230-256.

http://www.intechopen.com/books/food-additive/the-use-ofblood-and-derived-products-as-food-additives.

Pietrasik,Z., Jarmoluk, A. \& Shand, P.J. 2007. Effect of non-meat proteins on hydration and textural properties of pork meat gels enhanced with microbial transglutaminase. LWT: Food Science and Technology 40: 915-920.

Qal'aji, Muhammad ibn Rawas. Al-Mawsu'ah al-Fiqhiyyah alMuyassarah.Cet.1. 1996. Qaherah: Dar al-Hadith. hlm. 113.

Rumanta, M. 2007. Fisiologi Haiwan. Jakarta: Universitas Terbuka.

Sa'dom, N.B., Abdullah, A. \& Adnan, A.M. 2008. Detection of non-fish plasma protein in surimi and surimi-based products. Abstracts of the 23rd Scientific Conference of the Nutrition Society of Malaysia.

Saguer, E., Davila, E., Toldr, M., Fort, N., Baixas, S. \& Carretero, C. 2007. Effectiveness of high pressure processing on the hygienic and technological quality of porcine plasma from biopreserved blood. Meat Science 76(1): 189-193.

Sahilah Abd. Mutalib, Wan Sakeenah Wan Nazri, Safiyyah Shahimi, Norhayati Yaakob, Norrakiah Abdullah Sani, Aminah Abdullah, Abdul Salam Babji \& Maaruf Abd. Ghani. 2012. Comparison between pork and wild boar meat (Sus scrofa) by polymerase chain reaction-restriction fragment length polymorphism (PCR-RFLP). Sains Malaysiana 41(2): 199-204.

Sa‘id Hawwa. 1994. al-Asas fi al-Sunnah wa Fiqhiha, j. 1, Mesir: Dar al-Salam. hlm. 303.

Takahata, Y., Kurisaki, J., Mizumachi, K., Shibata, R., Shigehisa, T. \& Morimatsu, F. 2000. IgE-antibody specificities of the patients allergic to meat products. Anim. Sci. J. 71(5): 494500 .

Turubatovic, L., Vojinovic, G.V., Matekalo, S.D., Spasic, M.A. \& Dobrosavljevic, M. 1993. Sterilization of slaughterhouse blood products by ionizing irradiation. Technolog. Mesa.34: 75-78.

Uchman, W., Zabielski, J.P., Konieczny \& Fiszer, W. 1986. Radiation pasteurization of bovine blood plasma. I. Effects of dose on the total number of aerobic bacteria of liquid and spray-dried preparation. Acta. Aliment. Pol. 12: 177-185.

Waleed Khalid al-Rabi'. 2007. Ahkam al-At'imah fi al-Fiqh alIslami. Beyrut: Dar al-Nafais. hlm. 83.

Wilde, P., Mackie, A., Husband, F., Gunning, P. \& Morries, V. 2004. Proteins and emulsifiers at liquid interfaces. Advances in Colloid and Interface Science 108-109: 63-71.

Mohd Izhar Ariff Mohd Kashim*, Mohammad Zaini Yahaya \& Muhammad Adib Samsudin

Jabatan Syariah, Fakulti Pengajian Islam

Universiti Kebangsaan Malaysia

43600 UKM Bangi, Selangor Darul Ehsan Malaysia

Nur Asmadayana Hasim

Institut Islam Hadhari

Universiti Kebangsaan Malaysia

43600 UKM Bangi, Selangor Darul Ehsan

Malaysia 
Rizafizah Othaman dan Rozida Khalid

Pusat Pengajian Sains Kimia dan Teknologi Makanan

Fakulti Sains dan Teknologi

Universiti Kebangsaan Malaysia

43600 UKM Bangi, Selangor Darul Ehsan

Malaysia

Diani Mardiana Mat Zin

Kolej Permata Insan, Universiti Sains Islam Malaysia Bandar Baru Nilai

71800 Nilai, Negeri Sembilan Darul Khusus

Malaysia
*Pengarang untuk surat-menyurat; email: izhar.ukm@gmail.com

Diserahkan: 6 Januari 2017

Diterima: 21 Februari 2017 